\author{
LET: Linguistics, Literature and English Teaching Journal \\ ||Volume|| 9 ||Issue|| 1 ||Pages|| 22-51 || 2019 || \\ |P-ISSN: 20869606 ; E-ISSN: 25492454| \\ Available online at: http://jurnal.uin-antasari.ac.id/index.php
}

\title{
A STUDY ON THE REGISTER OF POLITY
}

\author{
Radityo Tri Nugroho \\ Radityotrinugroho88@gmail.com \\ Universiti Pendidikan Sultan Idris
}

Afifah Linda Sari

alindapersad@gmail.com

Antasari Islamic State University

\section{Article History:}

Received: $18^{\text {th }}$ April 2019

Accepted: $2^{\text {nd }}$ May 2019

\section{Corresponding}

Author:

Tel.:

\section{Keywords}

The Language of

Indonesian Politics;

Polity Register;

The Kinds of meaning

Polity Register

\begin{abstract}
The language of Indonesian politics is quite interesting. There are many phenomena of language abuse such as language manipulation and meaning reduction, which often occur. This research is meant to find 1) the form of the polity register, 2) the kinds of meaning polity register and 3) the characteristics of the polity register. Dealing with the research method, the writer applies qualitative method. The writer takes the data from the Indonesian newspaper "Suara Merdeka" which contains register polity. She collects the data by reading, scrutinizing, and listing them. To analyze the data, the writer uses semantic analysis based on Poedjosoedarmo theory to determine the changing meaning of the register. Having analyzed the data, the writer finds two forms of polity register namely: word and phrase. The words are in the form of simple word $(26,7 \%)$, compound word $(26,7 \%)$, and complex word (24, 4\%), abbreviation and blended, each has 2,2\%. In the form of phrase $(17,8 \%)$ Related to the meaning, the writer finds five kinds of changing meaning, namely: narrower than the real meaning $(8,9 \%)$, share some features whereas each of them has different meaning $(24,5 \%)$, identical to the real meaning $(13,3 \%)$, and different from the real meaning $(53,3 \%)$. Meanwhile, the Language styles of Indonesian polity register are euphemism $(57,7 \%)$, metaphor $(6,7 \%)$, hyperbola $(13,3 \%)$, and metonymy $(22,2 \%)$. The result of this research shows that the biggest amount of the register meaning of the Indonesian polity is different from the real meaning and tends to be euphemism. Those phenomena indicate that the polity register used by Indonesian politician tends to hide the real meaning. These may happen since there are some interests behind the Indonesian polity register, among others are to maintain and to retain power. In sum, the register is used to keep the authority goes on.
\end{abstract}




\section{INTRODUCTION}

People as zoon politicons always need to do interaction. Nobody can interact with others without language. In the interaction setting, people may use many kinds of language variation, which reflects changes in situational factor, such as addresses, setting, and topic. Every language has a different style, which depends on many factors, for example: dialect, social status, idiolect, area, oral \& written text, creating words system and new expression (Nababan in Sutopo, 1997: 70). In other words, it is obvious that language style also influences the language use. People utilize the specific vocabulary associated with different occupational groups or people's understanding.

There are so many groups in our life, although they live in the same society. They are doctors, teachers, and politicians, even athletes. Each group of people has its own vocabulary to express its feeling. The politicians' community uses their own vocabulary in communication that cannot be understood by other community.

Polity generally tends to discuss power, authority, and influence. Political world deals with how to organize the mass and how to persuade people to build public opinion. Therefore, to master public opinion it requires a medium of communication; language.

Political language is the language, which is used to reach the aim of polity (Nimmo, 1993: 75). In fact, to convey the message, politicians often use a particular word, which has different interpretation from real meaning. For example, the word suksesi (succession) universally has semantic feature keberhasilan (success). Meanwhile, the word suksesi in political world does not mean success, instead it means change the ruler, for instance the president. A particular word such as the word suksesi is usually called a register

Register means the language of a group of people with common interest or job or the language used in situation associated with such group. Holmes (1992: 72) argues that register is usually characterized by vocabulary differences; either by the use of particular words or by use of the words in particular sense. 
Common people may not understand the special language used in polity when they get in touch with it because the meaning that appears at the surface is not always the same as the real meaning. In the political realm, politician uses language strategy not only to attack the rivals but also to produce certain effect. They use language not only to express idea but also to hide it because there is an interest behind of the idea. For example, "Tidak sesuai dengan prosedur dan inskontitusional”. (Megawati. S. P. Republika 8 Juni 2001). The statement conveyed by Megawati as vice president during Abdurraman Wahid administration shows disagreement with President Abdurrahman Wahid's policy. The aim of the statement is to create opinion that what the president has done is wrong by using the word "Tidak sesuai dengan prosedur dan inskonstitusional" misprocedure and unconstitutional. The term is the example of euphemism, which tends to mean pelanggaran sistem (breaking the law.)

Language phenomenon used by Indonesian politician is very interesting. Language abuse such as, language manipulation, meaning reduction often occurs (Anderson in Danang, 2003: 3). This indicates that Indonesian political language is a sign or reflection of diseases.

In Polity, there is unequal communication between politician and common people. Politicians with their own power always empower language for their interest. Consequently, it raises some phenomena in which common people often do misinterpret the political language of politicians.

Every regime in Indonesia has its own characteristics of political language. Each of three regime; Old Regime, New Regime and Post New Regime has its different repertoire. Linguistically, the differences show at the level of vocabulary, grammar, and text structure. The term of Old Regime is concerned with the word revolusi to describe that Indonesia did a big revolution. Meanwhile, the term New Regime is concerned with the keywords pembangunan (development) to express that Indonesia is a developing country. The terms that appear are reflections that are the political elites. Political language at the end of New Regime (Post New Regime) must have characteristics, which are different from the previous regimes.

Political language of Post regime has so many kinds of term that have different meaning from the previous regimes, for example: the word $K K N$. During 
New Regime era the term KKN was only popular among university student community as abbreviation of Kuliah Kerja Nyata (The Real Field Work) which refers to the compulsory (rural) social action internship for advance university students. Meanwhile, at the end of New Regime (the reform era) the term KKN is more popularly related with Korupsi, Kolusi, and Nepotisme (Corruption, Collusion, and Nepotism) that is full of political nuance.

Because of the uniqueness of special language used in polity, the writer is interested in doing research closely related with register used in polity. The writer thinks that it is very important to study register used in political world. Thus, the writer decides to conduct a study entitled "A Study on the Register of Polity".

Some previous researchers have ever done concerning with the studies on Register: Diana Imama (2002) in her research "A Semantic Analysis on the English Register of the internet". She finds that register in the Internet is in form of word and compound word. Generally most registers are new words and do not have real meaning.

Alvari Kunto Prabowo (2001) is the next researcher who studies register. In his study "Analysis on English register Used in Formula I Championship", he reveals that the register is created by the race component and most of them are different from the original words. Alvari also finds that the real meaning and the contextual meaning of each register have indirect relationship. Moreover, there is no certain basic rule in making the register. The register is classified into the aerodynamic register, circuit \& race terms register and technique register.

Ralp Heri (2001) conducted the similar research. In his research "A Descriptive Analysis on Register Used in National Basketball Association (NBA) Games in united states in America", he finds that generally register is in the form of word and phrase. He also finds that each register which is used to represent one event that happen in either game. His study shows that the differences in meaning between general meaning and the contextual meaning of each register are quite significant.

The other researcher who has similar topic is Slamet Widodo (2004) that is "Register Export-import document". He finds three categories of the language 
forms, namely: word, abbreviation and phrase. He also finds the other form of relation of meaning among words namely: polysemy \& homophony.

Meanwhile, Nur Liana Imama (2003) describes the register used by Doctors and Nurses in dr. Sarjito Hospital Yogyakarta. She finds that mostly the meaning of the register does not have the real meaning.

From those studies, it is clear that there is no study of register on Polity. Therefore, this study will fill the absence of the study under the topic of register used in political world.

\section{LITERATURE REVIEW}

\section{A. Register}

\section{Notion of Register}

Register is considered to be language variety, along with dialect, slang, and jargon`. Example of register in this framework includes aviation language, journalese, legalese, literary language, scientific language, technical language, and mythical language (Biber, 1994: 51). The term register narrowly describes the specific vocabulary associated with different occupational groups. Holmes (1992: 276) notes that the register is the language of group of people with common interest, job, or the language used in situation associated with such group. In some sense register is 'in-group', which leads to express and speedy communication of information among those who know and use them but are confused those who don't. A politician has particular words to keep the power goes on.

Biber (1994: 51) states that register as a communication that recurs regularly in a society (in term of participant, setting, communicative function, and so forth) will tend overtime to develop identifying markers of language structure and language use is different from the language of other communication situation.

Wardhough (1977: 162) argues that register is the particular vocabulary choices made by individual or a group to fulfill the variety of language function to add up communication. Meanwhile, Biber and Figenan (1994: 316) note that register is a term for the full range of language varieties associated with difference in communicative situation. Of course, register is included in sociolinguistic study. Sociolinguistics is the study of language in use. If sociolinguistic is a wide- 
ranging term, register is equally tough to corral. Broadly conceived, a register is a language variety that is viewed with respect to its context of use.

Register is a set of language items associated with discrete occupational or special groups. As Fergusson (1994: 20) states people participating in recurrent communication situation tend to develop similar vocabularies, similar features of intonation, and characteristic bits of syntax and phonology that are used in a situation is called register.

In Summary, it is clear that register is a language variety used in certain community, which has specific meaning distinguished according to use. It is socially typical; it is used in certain situation, occupation/ certain groups and usually has certain purposes. The writer considers the register here as vocabulary.

\section{Forms of Register}

a. Word

A word is the smallest meaningful unit that can be used independently to convey meaning (Katamba 1994: 56). Based on the definition of morphology, word is the smallest free form that forms language. According to Srijono (2001: 51 ), word is the smallest free form found in language. Free form means that word can stand by itself. Example of word is house. Baurer (in Yule 1985: 7) also notes that there are same forms of word such as simple word, blends, clip word, acronym and abbreviation.

1. Simple word: simple word is a word that consists of a single morpheme. For example: train, boy, and book.

2. Blended: blending is the fusion of two words into one, usually the first part of one word with the last part of another, so that the resultant blends consist of both original meaning. For example the word motor and hotel became motel, which is used to mean a hotel for motorist.

3. Clipped Word: clipping is a process in which a word is formed by shortening a longer one, such as zoological garden becomes zoo.

4. Acronym: acronym is the result of forming a word from the first letter or letter of each word in phrase. Such as radar (Radio detecting and ranging)

5. Abbreviation: abbreviation is shortened form, especially of word. Yule (1985) states that another reduction process of word is the use of 
initialization or usually called abbreviation such as: FBI that stands from of

Federation Bureau of Investigation. The capital letter is sounded separately.

b. Compound word

Compound word is a word formed by combining of two independent words to create lager word and the resulting meaning is new or different from its elements. For example: greenhouse.

c. Phrase

Phrase is group of words (often without finite verbs) forming part of sentence. A term phrase used in grammatical analysis refers to a single element of structure, typically containing more than one word and lacking subject, predicate structure type of clause. Hornby (1974: 629) classifies phrase into following forms: verb phrase, noun phrase, participial phrase gerund phrase, and adjective phrase.

\section{Kinds of Meaning}

Every register human being produced has its own meaning. Sometimes it is difficult to deliver the massage because in the same term some people have different interpretation from others. It is also concerned with the context and the user of register.

According to Larson (1988: 271), meaning can be classified into four, namely:

a. Lexical meaning: the meaning that is given by dictionary. For example: the word chair in the dictionary has meaning moveable seat with a back, for one person.

b. Grammatical meaning: the meaning that is expressed by grammatical ending, word or intonation or the part of meaning that varies from one paradigm of others. For example is the word can. The meaning can be possibility and container for food or liquids. It depends on where the position of the word in a sentence. In a sentence they can read, the word can has function as auxiliary verb form. Meanwhile, in the sentence he kicked the can hard, the word can function as an object in noun form.

c. Textual meaning: the meaning that is acquired from relationship between one word to another in a sentence. For example is morphology. The word 
morphology in the Biology text is scientific study of the form and structure of animals and plants. While in the linguistics text the word morphology is a study of form of words.

d. Contextual meaning: the meaning that rises from situation, phrase, and sentence is used. For instance: Do you smoke? The interpretation of possible and effect can be strongly influenced by situation in utterance where it takes place. If the question Do you smoke? is asked by a physician, it does not function as a means of starting a conversation, but as a medical question.

\section{B. POLITY}

\section{Notion of Polity}

Polity is a general term that refers to political organization of a group. It is often used to describe a loosely organized society such as a tribe or community, but it can also mean any political group including a government or empire. It is also used to describe religious political organizations, particularly Christianity. Subtypes of polity include hierarchical, Presbyterian, and congregational. Aristotle described a polity as rule by the many, who are neither wealthy nor poor, in the interests of the whole community (Wikipedia, free encyclopedia 2005).

As it is written in Webters School Dictionary (1980: 1788), polity is political organization, a form of political organization, politically organized, and the form of government of religious denomination. The term polity can be separated from the politician. The politician as a main actor of polity has an important role. It is defined in Bewers dictionary of politic in Beard (2000: 7) that politician is a practitioner of the art of politics, essential to working of human society but frequently despised by those outside the political arena. Indeed, the word is sometimes abused. The word politician in denotative meaning has definition is person who is practically engaged in running a country, district or town. However, the connotative meaning surrounding the word politician is nearly negative.

\section{Characteristics of the Political Language}

Political language is the language, which is used to reach the aims of politic. According to Beard (2000: 6), political language is a language used by politicians. The features of political language vary, as do its purposes. Where politicians 
interact with society generally, their purposes may be to persuade voters with a party loyalty to turn out to vote, to move a floating voter's party allegiance, or to make people adopt general political or social attitudes, so the people support a given policy. According to Dan Nimmo (1993: 102), politicians in provoking the mass often use the language, which contains euphemism, symbol, hyperbole, and metaphor.

a. Euphemism refers to something offensive or delicate to make it sound more pleasant or acceptable than really is. For example, pass away is used to replace the word die.

b. Metaphor, as is it told by Aristotle (in Graves \& Mc Bain, 65), gives something a name that belongs to something else. For example, life is fire. From the example it is clear that the writer compares directly the life as fire, life is so hard and dangerous. If people are not careful, it can burn them like fire. In addition, Beard (2000: 19) notes that metaphor refers to word or phrase, which is used to establish comparison between one idea and another.

c. Puffery (Hyperbola) or overstatement is simple exaggeration in the service of truth (Perrine, 1977: 102). For example, the river boils through the sentence. The word hot never appears yet; a practical reader is to bond to interpret or to associate boils as hot. Since the authors describe extremely hot water by means of such an expression, the writer creates a hyperbole.

d. Symbol is defined as something that means more than what it is (Perrine, 1977: 81). For example, this is the hour. From the example, hour is the use of figurative meaning of something that is not the character of the object itself. This means that it is time to start a new life where people can change their life style to make life better.

e. Metonymy, involves replacing the name of something with something that is connected to it. For example, "The White House today threatened Saddam Hussein with military action over the UN inspector affair." The metonymy "White House" represents the president of United State, his advisors and government. "Saddam Hussein" represents the country or people of Iraq.

\section{METHOD}


The writer employs the qualitative research. Moloeng (1983: 3I) affirms that qualitative research is a research of which the data in the forms of written and oral words are descriptively analyzed. In slightly different way, Milles and Hubberman (1992:2) maintain, "Qualitative data tend to be in the form of words than series of number". It does not present data and research result in the form of digits or statistic but it yields the data and the results in the form of phenomenon description.

The object of the study is the register used in political language that takes from the Indonesian newspaper "Suara Merdeka" which contains register polity.

The source of data refers to the subject from which the data are obtained. They are considered as the material of the research. The data of this research are register used in Indonesian Polity at the B.J. Habibie administration period. The data are Javanese, Indonesian, and English words that are taken from Indonesian newspaper such as "Suara Merdeka" published on October, November and December 1998.

In collecting the data, he employs the steps as follows: (1) Reading the newspaper; (2) The second step is scrutinizing the data and selects the data that belong to polity register; (3) The third is taking a list of polity register.

The technique of data analysis used in this study is descriptive qualitative analysis. This study will use such kind of technique to analyze the meaning of register and the characteristic of it. The steps to analyze the data are as follows: (1) Classifying the register into form of register into each element of words, abbreviation and phrase; (2) Elaborating the register meaning based on classification above; (3) Defining the register according to its characteristic.

\section{FINDINGS AND DISCUSSIONS}

\section{Data Analysis}

\section{The Similarities between English and Indonesian Passive voice.}

a. Word
1) Simple Word
Simple word is a word that consists of single morpheme. The example of simple word describes as follows: 
a) Anarchy

"The anarchy political condition will increase in 1999"

The term anarchy is called simple word because it a single morpheme and does not has affixes.

b) Cendana

"The former Minister of Defense and Security denies that his party is funded by cendana family".

The term Cendana is called simple word because it a single morpheme and does not has affixes.

c) Euphoria

"B.J. Habibie states that the aim of the law discussion is to realize immediately the final process of reformation so that the euphoria will also too comes to an end soon".

The term euphoria is called simple word because it a single morpheme and does not has affixes.

d) Crony

"The land of Suharto and his crony have been known just between 6 areas and 9 areas".

The term crony is called simple word because it a single morpheme and does not has affixes.

e) Koalisi

"PAN will do Coalition with any party as long as having the same platform".

The term coalition is called simple word because it does not has affixes.

f) Longer

"Although Soeharto has Lengser he still has a power".

The term Lengser is called simple word because it a single morpheme and does not has affixes.

g) Makar

"Pakpahan is declared guilty by the court because of a Makar act".

The term makar is called simple word because it a single morpheme and does not has affixes. 
h) Manuver

"The meeting of Suharto and Gus Dur is a political maneuver only".

The term maneuver is called simple word because it a single morpheme and does not has affixes.

i) Referendum

"The referendum holding needs a preparation in order that the society be able to know and understand the real condition so that they may accept the result of referendum".

The term referendum is called simple word because it a single morpheme and does not has affixes.

j) Radical

"What must be alerted, adds Juwono, is that university student action is frequently infiltrated particularly by the non university student radical group".

The term radical is called simple word because it a single morpheme and does not has affixes.

2) Complex Word

Complex word is a word that contains two or more morphemes.

a) Oposan

"It's better for Golkar to be an opposition".

The term oposan is derived from English word opposition. The term opposition is called complex word because it consists of two morphemes: opposite (Free morpheme) and \{-ion $\}$.

b) Recalling

"Recalling is a manifestation of the Golkar frightening on (Indonesian Democratic Party) PDI as a real power".

The term recalling is called complex word because it consists of three morphemes: $\{$ Re- $\}$, call (Free morpheme) and $\{-$ ing $\}$.

c) Reformation

“The People's Consultative Council (MPR) did not make fundamental reformation problem decision, but the only the marginal one". 
The term reformasi is derived from English term, reformation. It belongs to complex word because it consists of three morphemes: $\{\mathrm{Re}-\}$, format (Free morpheme) and \{-ion $\}$.

d) Reshuffle

"This is the best time for President BJ Habibie to reshuffle his cabinet". The term reshuffle is called complex word because it consists of two morphemes: $\{$ Re- $\}$ and shuffle (Free morpheme).

e) Status Quo

"Do not make decision which preserves Status Quo".

The term status quo is called complex word because it consists of two morphemes. Status and Quo.

3) Compound Word

Compound word is a word formed by combining of two independent words to create lager word and the resulting meaning is new or different from its elements.

a) Platform

"PAN will do coalition with any party as long as having the same platform".

The term platform is called compound word because it combine from two independent of words: plat (noun) + form (noun) which create the larger word that the new meaning is different from its elements.

b) Trademark

"Amien should keep his nation trademark going on".

The term trademark is called compound word because it combining from two categories of words which create the larger word that has new meaning. The meaning of trademark cannot be predicted by the lexical meaning of trade and mark. the compound has new meaning which is different from its elements.

c) Sidang Rakyat

"In the people assembly students will insist three demands which are not accommodated by People's Consultative Council, MPR and special assembly". 
The term people assembly is called compound word because it combines from two lexical categories of words: people and assembly, it creates the larger word that has new meaning which is different from its elements.

d) Political Cosmetic

"The interpretation is negative, the opinion is a political cosmetic only"

The term political cosmetic is called compound word because it combines from two lexical categories: (Political and cosmetic) which create the larger word that the new meaning which is different from its element.

e) Money Politic

"He promises that he would like to hold PAN to be the most Democratic Party and does not do money politik".

The term money politik belongs to compound word because it creates new meaning or special meaning, and special meaning can be determined from of its part (the meaning of money and the meaning of politik).

4) Blended

Blending is the fusion of two words into one, usually the first part of one wor with the last part of another.

a) RATIH (RAKYAT TERLATIH).

"The aim of RATIH establishment is not to against each other".

The term RATIH belongs to the blended category because it a fusion of two words into one, the first part word (rakyat) with the last part word (terlatih).

5) Abbreviation

Abbreviation is the shortening form of the phrase by taking the first letter.

a) $\mathrm{KKN}$ (Korupsi, Kolusi, Nepotisme).

"The judiciary will immediately accomplish Corruption, Collusion, and Nepotism (KKN) case as the first commitment"

KKN is called abbreviation because that is short form by taking the first letter. Korupsi, Kolusi, Nepotisme.

b. Phrase 
Phrase is regard as a grouping of one or more words that focus around a head word for example a noun phrase has a noun headword.

1) Noun Phrase

a) Agenda Reformasi

"The Reformation Agenda is not only how to create the democratic authority system"

Agenda Reformasi is called noun phrase because it has the head " Agenda" and modifier " reformation. The structure: Agenda (noun) + Reformation (noun), it is a noun phrase with the head is agenda

b) Elite Politic

"The central Java Regional Deputies Broad of KNPI calls on elite politic to restrain their desires".

Elite Politik is called noun phrase because it has the head " politik" and modifier " elite". The structure: politic (noun) + elite (noun), it is a noun phrase with the head is politic.

c) Laskar ORBA

"Hamzah Haz will lead the Leadership of Political party at Regional level (DPP) for 1998-2003 period that has the members of the remaining people of laskar orde baru".

Laskar ORBA is called noun phrase because it has the head "Laskar" and modifier "ORBA". The structure: Laskar (noun) + Orba (noun), it is a noun phrase with the head is laskar.

d) Move Politik

"Kwik kian Gie assumes that the FPP and FKP opinion is a political movement only to reach the pseudo support".

Political movement belongs to noun phrase because it has the head "movement" and modifier "political". The structure: political (noun) + movement (noun), it is a noun phrase with the head is movement.

e) Pemerintah transisi

"The Habibie's administration is just a transitional government".

Transitional Government belongs to noun phrase because it has the head "government" and modifier "transitional". The structure: government 
(noun) + transitional (adjective), it is a noun phrase with the head is transitional.

2) Adjective phrase

a) Radical Revolutionary

"Habibie knows that there is a tendency of a group of society to do radical revolusionary “"

Radical Revolutionary belongs to adjective phrase e because it has the head "revolutionary" and modifier " radical". The structure:

revolutionary (adjective) + radical (adjective), it is a noun phrase with the head is sovereignty.

\section{The Kinds of Meaning of Register Polity}

a. The real meaning is narrower than register meaning

1) Crony

"The land of Suharto and his crony have been known just between 6 areas and 9 areas".

The lexical meaning of the term crony is "close friend" (Hornby, 1995: 277). Meanwhile, in the Indonesian political context the term crony has negative sense/meaning. It refers to the "particular Suharto's colleagues especially for those who are government officials"They are usually suspected to have done Collusion, Corruption and Nepotism. The register meaning is narrower than the real meaning.

2) Euphoria

"BJ Habibie states that the aim of the law discussion is to realize immediately the final process of reformation so that the euphoria will also to come to an end soon".

The lexical meaning of the term euphoria is "an intense feeling of happiness and pleasant excitement" (Hornby, 1995: 394). Meanwhile, the register meaning is a condition in which the people feel so happy and over enthusiasm to do reform movement in all way including doing the destructive action to express unbearable emotion that is inhibited for 
along time during the New Order Regime. The register meaning of the term euphoria is narrower than the lexical meaning.

\section{3) Koalisi}

"The land of Suharto and his crony has been known just between 6 areas and 9 areas".

The lexical meaning of the term crony is "close friend" (Hornby, 1995: 277). Meanwhile, in the Indonesian political context the term crony has negative sense/meaning. It refers to the particular Suharto's colleagues especially for those who are government officials. They are usually suspected to have done Collusion, Corruption and Nepotism. The register meaning is narrower than the lexical meaning.

b. The real meaning is identical with the register meaning

1) Konstitutional

"The general election is considered as the only one constitutional medium to continue reform movement".

The lexical meaning constitutional is "something that allowed by or limited by a constitution "(Hornby, 1995: 247). The register meaning of the term constitutional is the same as the real meaning.

2) $\mathrm{KKN}$

"The judiciary will immediately accomplish Corutption, Collusion, and Nepotism (KKN) case as the first commitment".

The term KKN (Korupsi, Kolusi, Nepotisme) is intensively used by some politicians. The use of this abbreviation is much more effective than the long one. This term becomes an identity of status Quo. This term does not have a new meaning. The meanings of each word are:

Corruption: "The act of corrupting" (Hornby, 1995: 261) is such kind of bribery act or disusing of the fund of state/organization.

Collusion: "A secret agreement or understanding between two or more people with the aim of deceiving or cheating others" (Hornby, 1995: 221). 
Nepotism: "The practice among people with power or influence of favouring their own relatives especially by giving the job" (Hornby, 1995: 779).

The register meaning is same as the real; meaning

3) Agenda reformasi

"The Reformation Agenda is not only how to create the democratic authority system".

The above sentence has a register in the form of noun phrase. When we give meaning of each word, agenda means "the matter of business to be discussed" (Hornby, 1995: 23). While the reformation is "the action of reforming something"(Hornby, 1995: 980). Lexically, the term Reformation agenda is the matters of business to be discussed in the action of reforming something.

Meanwhile, the contextual meaning refers to the things demanded to be changed and fulfilled by the government, among others are:

a) Eradicating the case of corruption, collusion, and nepotism.

b) Bringing Suharto into the court.

c) Dismissing the New order.

The register meaning is identical with the real meaning

4) Elite Politik

"The central Java Regional Deputies Broad of KNPI calls on elite politic to restrain their desires".

This term is taken from the word elite and politic and combined to be a noun phrase. The lexical meaning of the word elite means "a group considered to the best or most important because of their power" (Hornby, 1995: 374).

The contextual meaning of the term Elite politik is" people who have a main position in political institution such kinds of the party leader". The junior usually obeys them and their speeches have great influence in shaping public opinion. The register meaning is same as the real meaning.

5) Pemerintah transisi 
"The Habibie's administration is just a transitional government".

The lexical meaning of the word transitional is one holding power of a temporary a period of change. It means that the Habibie's government is "temporal government to replace the absence of government before the new authority is formed". The register meaning is the same as the real meaning.

c. The real meaning is different from the register meaning

1) Anarkhis

"The anarchy political condition will increase in 1999".

The lexical meaning of term anarchy is "the absence of government or control in society" (Hornby, 1995: 38). Meanwhile, in the political context the term anarchy refers to"such a kind of action which tends to mean a destructive action and disobeys the norm and constitution". it is probably caused by the inability of the government to control what the people want to do since they do not respect the government any more. The register meaning is different from the real meaning.

2) Condone

"The former Minister of Defense and Security denies that his party is funded by cendana family".

The lexical meaning of the term cendana is a kind of plant or flower which has hard wood with sweet smell. Meanwhile, in political context this term means as the "Suhartos". The term cendana here refers to the address where the Suhartos live in. It refers to the name of street, Cendana Street. The register meaning is quite different from the real meaning.

3) Makar

"Pakpahan is declared guilty by the court because of a coup de tat act".

The real meaning of the word makar is trickery. The lexical meaning of the term makar is "revolt the action or stated of protesting against or resisting authority" (Hornby, 1995: 1008). In political context the term makar is revolt against the authority, which is done smoothly (Coup de tat). The register meaning is different meaning 
4) Radical

"What must be alerted, adds Juwono, is that university student action is frequently infiltrated particularly by the non-university student radical group".

Terminologically meaning of the term radical is basic or root. The lexical meaning of the word radical is "favoring thorough or complete political or social reform holding extreme views" (Hornby, 1995: 985). The term radical is popular enough in political realm. It usually has negative sense. This term radical is often used to label "a group or people who do frontal and destructive movement against the authority". The register meaning is quite different from real meaning.

5) Recalling

"Recalling is a manifestation of the Golkar frightening on (Indonesian Democratic Party) PDI as a real power".

The lexical meaning of the word recalling is "to remind something in order that somebody/something return "(Hornby, 1995: 971). Meanwhile, the meaning of the term recalling in political context is recalling somebody to turn back to the party from certain position in political institution. The position in this case is usually higher than the previous position before being recalled. For example: the recalling of the Golkar members from MPR (People's Consultative Council).

The essence meaning of the word recalling is almost similar with reshuffle. It refers to the retiring action. The reshuffle is done by the senior figure that has higher position, for example is the reshuffle of cabinet done by president. Meanwhile, recalling refers to "an act to withdrawal off the cadre who is done by the party's leader". The register meaning is quite different from the real meaning.

d. The real meaning and register meaning can share some features of meaning whereas each of the has different meaning.

1) Lengser

"Although Soeharto has slide down he still has a power" 
The term lengser originally comes from Javanese word. The lexical meaning of this term refers to a movement from higher position into lower one. Meanwhile, in Indonesian polity context lengser is "an abdication from some political position". Usually this term does not stand alone but stand with keprabon, which textually means crown. Completely the meaning of lengser keprabon is the king's stepping down from his crown. This term is to express the presidential succession. This register is quite popular at the end of moment of the Suharto administration. The real meaning and the register meaning share some features whereas they have different meaning. Suharto as an act of retreat says this register. This term shares some feature with the real meaning but has different meaning

2) Manuver

"The meeting of Suharto and Gus Dur is a political maneuver only".

The lexical meaning of term maneuver is "a movement performed with care and skill" (Hornby, 1995: 714). This term is usually used in military field especially in aviation, which tends to mean a kind of difficult movement. Meanwhile, in political context the term maneuver refers to "an action of politician or political institution which is difficult to do due to having a high risk and dangerous effect". Maneuver refers to a skillful action in holding reform movement. The real meaning and register meaning are share some features whereas they have different meaning.

3) Legitimasi

“The result of Particular Assembly of people's Consultative Council (MPR) 1998 will not get the people legitimacy"

The lexical meaning of the term legitimacy is "allowed by law or by rules" (Hornby, 1995: 674). In political context this term refers to the people acknowledgment, meaning that the assembly is illegal and cannot be accepted by people, although accordance to law and constitution the assembly is legal. The register meaning and the real meaning share some features whereas each of them has different meaning 


\section{4) Oposan}

"It's better for Golkar to be an opposition".

The lexical meaning of the term opposition is "contrary position with somebody or something, the state or action opposing somebody/ something" (Horny, 1995: 814). In political context the register meaning refers to "the doer who opposes with government or the political institution that has contrary role with the government. The term opposition exists due to the party institution that does not get enough vote to get a position in parliament". Therefore, they choose to be a competitor to control the government. The register meaning and the real meaning share same features whereas each of them has different meaning.

5) Reshuffle

"This is the best time for President BJ Habibie to reshuffle his cabinet".

The lexical meaning of the word reshuffle is "to change around the jobs done by a group of people especially in a government" (Hornby, 1995: 997). Although reshuffle can be done in any field, this term is more popular in political realm. Reshuffle refers to "the reform of the cabinet structure due to mismatch of the cabinet skill with the job or the cabinet which do not have good performance". In fact, reshuffle is not only reforming or changing the cabinet structure but also making people retire early. This term shares some features with the real meaning but it has different meaning.

\section{The Language Styles of Register Polity}

a. Euphemism

Euphemism refers to something offensive or delicate to make it sound more pleasants or acceptable than really is. For example, pass away is used to replace the word die.

1) RATIH

RATIH (Rakyat Terlatih) is euphemism it makes term of semi military training sound more pleasant becomes people trained.

2) Krony 
Krony is euphemism of the Suharto and his group who do corruption, collusion and nepotism.

3) Koalisi

Koalisi is euphemism of the the fusion, fusion of two parties or more

4) Lengser

Lengser is euphemism off the an abdication act or retreat act.

5) Makar

Makar is called euphemism because it sound more pleasant than the trickery act.

6) Legitimasi

Legimasi is euphemism of the acknowledgment

7) Konstitusi

Konstitusi is euphemism of the legality

8) Oposan

Oposan is tends to means the competitor of government, it is more pleasant than the term competitor.

9) Reformasi

Reformasi is euphemism off the Changing, the great change especially in government.

10) Resuhffle

Reshuffle is tends to meant a retreat act.

b. Hyperbola

Hyperbola is simple exaggeration in the service of truth is gives something a name that belongs to something else. For example, life is fire. From the example it is clear that the writer compares directly the life as fire, life is so hard and dangerous.

1) Anarkis

Anarkhis is the overstatement of the uncontrolled situation

2) Euphoria

Euphoria is the overstatement of the felling happy.

3) Radikal 
Radikal is the overstatement of the destructive action

4) $\mathrm{KKN}$

$\mathrm{KKN}$ is the exaggeration of the crime act namely: Korupsi, Kolusi and Nepotisme

\section{5) Laskar ORBA}

It is called hyperbola because it the overstatement of the number of people not the in large number.

6) Radikal Revolusioner

It belongs to hyperbola because it makes sense of the term over than really is.

c. Metaphor

A metaphor is gives something a name that belongs to something else.

For example, life is fire. From the example it is clear that the writer compares directly the life as fire, life is so hard and dangerous.

1) Manuver

Maneuver refers to a skillful action in holding reform movement. The terms maneuver is a metaphor to make polity more vivid.

2) Agenda Reformasi

This term is a metaphor, which is used to describe that reformation has some agenda that have to do like human being.

3) Move Politik

This term is a metaphor. The usage of movement to describe that the polity is like human being that can move.

d. Metonymy

Metonymy is involves replacing the name of something with something that is connected to it.

1) Cendana

Cendana is represents of the Suharto family; cendana here refers to the name of the street where the Suharto lives in.

2) Status Quo

Status Quo is refers to the Suharto government 


\section{3) Pro Reformasi}

Pro Reformasi is represents of the group of people who do not agree with the Suharto administration to stay along.

4) Pro Status Quo

Pro Status quo refers to the group of people who agree with the Suharto administration to stay along.

5) Kelompok Ciganjur

Kelompok Ciganjur represents some names of elite politic, namely: Megawati, Gusdur, Sri Sultan, and Amin Rais.

6) Alat Negara

Alat Negara is something that can help the nation it refers to the military institution

7) Mesin Orba

Mesin ORBA refers to the Golkar because Golkar like a machine that always obeys and follows on the instruction of ORBA

8) Partai Hijau

Partai Hijau refers to the United Development Party "PPP"

9) Oposisi terbuka

Oposisi terbuka represents Kemal Idris and friends

10) Era Reformasi

Era Reformasi refers to the era after Suharto government.

\section{Discussion of the Finding}

Having analyzed all the data, the writer finds out several findings the arrange the findings which are divided into three classifications. i.e. finding based on the forms of the register, kinds of meanings and the characteristics of the polity register.

Following is a table of the result of the data classification based on the forms of the register, kinds of meaning, and the characteristics of the political language.

Table 1. The Classification of Polity Register 


\begin{tabular}{|c|c|c|c|}
\hline No & & \multicolumn{2}{|c|}{ Case } \\
\hline 1 & Forms of the Register & Number & $\%$ \\
\hline & 1) Simple Word & 10 & 22,2 \\
\hline & 2) Complex Word & 11 & 24,4 \\
\hline & 3) Phrase & 8 & 17,8 \\
\hline & 4) Compound Word & 14 & 31,1 \\
\hline & 5) Abbreviation & 1 & 2,2 \\
\hline & 6) Blended Word & 1 & 2,2 \\
\hline & $\Sigma$ & 45 & 100 \\
\hline 2 & Meanings of the Register & & \\
\hline & 1) Narrower & 4 & 8,9 \\
\hline & 2) Share some features & 11 & 24,4 \\
\hline & 3) Different & 24 & 53,3 \\
\hline & 4) Identical & 6 & 13,3 \\
\hline & $\Sigma$ & 45 & 100 \\
\hline 3 & The Characteristics of Political Language & & \\
\hline & 1) Euphemism & 26 & 57,7 \\
\hline & 2) Metaphor & 3 & 6,7 \\
\hline & 3) Hyperbola & 6 & 13,3 \\
\hline
\end{tabular}




\begin{tabular}{|l|l|c|c|}
\hline 4) Metonymy & 10 & 22,2 \\
\hline$\Sigma$ & 45 & 100 \\
\hline
\end{tabular}

As briefly seen in the table, for category of the form of the register polity, the writer found 14 terms $(31,1 \%)$ for compound word, 11 terms $(24,4 \%)$ for simple word, 10 terms $(22,2 \%)$ for complex word, 8 terms $(17,78 \%)$ for phrase, and for the blended and the abbreviation each has one term $(2,2 \%)$. It is clear that compound word category is the biggest number found $(31,1 \%)$. It means that the politician often use compound word in their speech. It may happen since the compound words usually have ambiguous meaning.

For the classification based on the meaning category, the table shows that there are 4 meanings in polity registers namely: the register meaning is narrower than the real meaning: 4 terms $(8,8 \%)$, the register meaning is identical with the real meaning: 6 terms $(13,3 \%)$, the register meaning and the real meaning share some of the feature whereas has different meaning: 11 terms $(24,4 \%)$, and the register meaning is different from the real meaning: 24 terms $(53,3 \%)$. From the table it is obvious that most of the register meaning $(53,3 \%)$ is different from the real meaning. It means that the register used in Indonesian polity has its own meaning and tends to occur semantic change. It may happen because the politicians do semantic monopoly, the politicians have authority to give meaning of the register.

For the last category related to the characteristics of the political language, the data show 26 terms for euphemism (57,7\%), 3 terms for metaphor $(6,7 \%), 6$ terms for hyperbola $(13,3 \%)$, and 10 terms for metonymy $(22,2 \%)$. It is clear that the euphemism is the most dominant category usually used. It means that the register in Indonesian polity is full of euphemism nuance; it is used to make things smooth so that the other do not realize what truly happen. Politicians use euphemism as a way to hide or manipulate reality in order to retain and maintain power by control the image development and attract the mass sympathy.

\section{CONCLUSIONS AND SUGGESTIONS}




\section{Conclusion}

Based on the form of the register, the writer finds two forms i.e. word and phrase. And the word are in the form: compound word, the simple word, complex word, phrase, and blended and abbreviation. The biggest number of term $(31,1 \%)$ is compound word. It means that the politician often use compound word in their speech. It happens since the compound words are usually ambiguous and tends to have different meaning.

Related to the meaning of the register, the writer finds four kinds of meaning, i.e. the register meaning is narrower than the real meaning, the register meaning is identical with the real meaning, the register meaning and the real meaning share some features whereas their meaning is different, and the register meaning is different from the real meaning. The most of the register meaning $(53,3 \%)$ is different from the real meaning. It means that the register in Indonesian polity has its own meaning and tends to occur semantic change. It may happen because the politicians do semantic monopoly, the politicians have authority to give meaning of the register.

Viewed from the characteristics of the political language, the writer finds 4 kinds of characteristics of the register polity, namely euphemism, metaphor, hyperbola, and metonymy. The result shows that euphemism is the most dominant term $(57,8 \%)$. It means that the register in Indonesian polity is full of euphemism nuance; it is used to make things smooth so that the other do not realize what truly happen. Politicians use euphemism as a way to hide or manipulate reality in order to retain and maintain power by control the image development and attract the mass sympathy.

\section{Suggestion}

Based on the result of this study, the writer would like to presents some suggestions as follows:

1. For the reader

The readers should be careful in identifying the meaning of the register of the polity in order to have better understanding and right interpretation.

2. For the politician 
a. The politician should be careful in using and empowering the language as a means of maintenance of the authority, because it has many implications; linguistically, sociologically, and psychologically.

b. The politician should be honest in delivery the message in order that the information distortion can be avoided

c. The politicians should select and choose the right words to avoid unequal information between politician and society.

3. For next researcher

a. Political language is very interesting and always changes. Therefore, the writer hopes there will be a researcher who will conduct the same topic but in different point of view, such as pragmatics, or discourse analysis frame work.

b. The writer hopes that there will be researcher who will complete the polity register.

\section{REFERENCES}

Alvari Kunto Prabowo. 2001. A Descriptive Analysis of Register Used in Formula I Championship. Unpublished S1 Research Paper. UMS.

Anam Sutopo. 2000. "Language Phenomena in Political Crisis" in Humanity. (Page 79- 92). Surakarta: Language Centre of Muhammadiyah University of Surakarta.

Beard, A. 2000. The Language of Politics. London: Routledge.

Biber, Douglas and Figenan. 1994. Sociolinguistic Perspective Register. New York: Oxford University Press.

Danang Santoso. 2003. Bahasa Politik Pasca Orde Baru. Jakarta: Wedatama Widyasastra.

Diana Imama. 2002. A Semantic Analysis on the English Register of the Internet. Unpublished S1 Research Paper. UMS.

Djoko Srijono. An Introductory Course of Liguistics. Surakarta: Muhammadyah University Press.

Dwi Purnanto. 2002. Register Pialang Kendaraan Bermotor. Surakarta: Muhammadiyah University Press.

Graves, BF and Mc Baic., D J. 1972. Lynes Voices: Approach to the Poetry of Contemporary Song. New York: John Willey \& Sons Inc. 
Hornby, A.S. 1995. Oxford Advance Learner Dictionary. Oxford: Great Britain.

Holmes, Janet. 1992. An Introduction to Sociolinguistics. New York: Longman.

Hymes, D. 1977. Foundation in Sociolinguistics. Cambridge: Cambridge University Press.

Katamba, Francise. 1994. English Words. London: Routlegde.

Larson, M L. 1988. Semantic Volume 1. Cambrige: Cambrige University Press.

Merriam. 1998.Webster's Third New International Dictionary. London: Enclycopedia Britanica. Inc.

Moeloeng, Lexi J. 1989. Metodologi Penelitian Kualitatif. Jakarta: Depdikbud Press.

Nababan, PWJ. 1991. Sociolinguistik: Suatu Pengantar. Jakarta: Gramedia.

Nimmo, Dan. 1993. Komunikasi Politik. Bandung: Rosda Karya.

Perrine, Lawrence. 1997. Sound and Sense: An Introduction to Poetry. New York: Harcout Brace Javanovich.

Ralp Heri. 2001. A Descriptive Analysis on Register Used in National Basketball.

Association (NBA) Games United State America. Unpublished S1 Research Paper. UMS.

Tim Bahasa. 2001. Kamus Bahasa Jawa. 2001. Yogyakarta: Kanisius.

Wardhough, Ronald. 1986. An Introduction to Linguistics. Blackwell: Cambrige.Zuhriah Ariatmi. 1997. Euphemisme dalam Surat Kabar Harian di Indonesia. Yogyakarta: UGM. 